\title{
Selection into Employment Sectors in Urban Ghana and Tanzania: The Role of Education
}

\author{
Priscilla Twumasi Baffour ${ }^{1} \&$ Festus Ebo Turkson ${ }^{1}$ \\ ${ }^{1}$ Department of Economics, University of Ghana, Ghana \\ Correspondence: Festus Ebo Turkson, Department of Economics, University of Ghana, Ghana. E-mail: \\ feturkson@yahoo.com
}

Received: November 26, 2015

Accepted: December 8, 2015 Online Published: December 16, 2015

doi:10.5430/rwe.v6n4p78

URL: http://dx.doi.org/10.5430/rwe.v6n4p78

\begin{abstract}
Recent debate among policy makers and researcher has centered on whether informal sector employment is a result of competitive market factors or labour market segmentation. This study contributes to the empirical literature by analysing selection into employment sectors in urban labour markets of Ghana and Tanzania using worker surveys from 2004 to 2006 in pooled sample models. Results from occupational choice models suggest both labour markets are characteristic of preference for formal sector employment with education. Results based on age differences indicate heterogeneity in job attainment as young people are found to face more challenges in accessing jobs.
\end{abstract}

Keywords: selection, sector choice, employment, unemployment, labour market

\section{Introduction}

The distinction between formal and informal sector employment has become the standard way to describe urban labour markets in developing countries especially the urban labour market structure in Africa. The formal sector is subject to regulations and the existence of explicit contracts between employers and employees. The informal sector on the other hand is not subject to government regulations and is dominated by individuals and small enterprises that employ few apprentices or hired labourers. An ILO mission to Kenya in 1972 defined economic informality in a broad context by the use of such characteristics as ease of entry, small scale of operation, family ownership, skills acquired outside the formal school system and unregulated and more competitive markets. The concurrent existence of the formal and informal sector is viewed as a result of labour market segmentation with formal sector wages above the market clearing rate that leaves a large pool of people unemployed. As a result, the informal sector is oversupplied with labour at strikingly lower earnings. Human capital theory offers possible explanations for earnings differentials by arguing that worker productivity explains earnings and sector choice (assumed to be utility maximising), despite the possible existence of sector earnings differences.

The position and nature of the informal sector compared to the formal sector is crucial for the functioning of the labour market and the overall economic structure in countries with a large informal sector. It affects income distribution (inequality) and poverty and has implications for efficiency in terms of allocation of labour and the distortions in the formal sector due to taxes, social security and labour market regulations. This explains why the role of the informal sector has recently been analysed extensively.

The literature on labour markets presents two competing views, the staging hypothesis (market segmentation) and the symmetric market assumption. The traditional staging hypothesis (Fields, 1975) is an expansion of the Harris-Todaro model which formalised Lewis (1954) concept of labour market dualism. The theory postulates that formal sector employment is rationed, those unable to obtain formal sector jobs and cannot afford to be unemployed while they search, work in the informal sector. Based on the dual labour market model, the informal sector is considered as a residual component of the market with informal sector workers who suffer from poor labour market conditions queuing for better jobs in the formal sector. Boudarbat (2004) supports this with the observation of a preference for public sector employment in Africa and a willingness of the educated to engage in 'wait' unemployment to secure well paid and stable public sector jobs. The segmentation hypothesis therefore sees informal employment as a strategy of last resort to escape involuntary unemployment.

The second view sees the informal sector as competitive to the formal sector (symmetric market assumption) with 
the two sectors characterised by different production functions. As a result of this heterogeneity, some workers are more productive in the formal sector and others in the informal sector.

The competitive market hypothesis views informal employment as a voluntary choice by workers based on income or utility maximisation. Voluntary employment in the informal sector can be due desirable non-wage features of the informal sector where individuals maximise their utility rather than their earnings (Maloney, 2004). Recent empirical evidence suggests that the real situation is a mixture of these two hypotheses (Maloney, 1999, 2004; Perry, Maloney, Arias, Fajnzylber, Mason, \& Saavedra-Chanduvi., 2007).

Empirical evidence on labour market segmentation and sector choice in Africa point to some form of sorting process in order for workers to be situated in a particular employment status. Therefore, when an individual takes the decision to participate in the labour market, we seek to identify which personal and socioeconomic characteristics are important. Specifically, what labour supply factors are associated with a greater or lesser likelihood of employment in the formal public or private sectors, the informal sector (self-employment) and not-working (unemployment). With the informal sector as the fastest growing segment of the labour force in both rural and urban areas in Africa, it is imperative to analyse available data to highlight the characteristics for selection into the different employment sectors to sheds light on heterogeneity or any existing discrimination in the labour market.

Consequently, the study applies a baseline model of participation to shed light on determinants of participation and further adopt a multi sector model to investigate determinants of participation in the formal public and private sectors in addition to the informal sector in both Ghana and Tanzania.

This study is important because it offers an insight into the factors that determine labour selection into employment sectors in Ghana and Tanzania, two typical African countries facing grappling with high unemployment and underemployment. Finding from the study will inform policy making in Africa, as the sub region intensifies efforts to reduce unemployment through the creation of decent jobs so as to ensure income security, wealth creation and ultimately poverty reduction.

In addition, youth unemployment is an important issue in both developed and developing countries. Youth unemployment is substantially higher than global adult unemployment and has been growing in the last decade (International Labour Organisation [ILO] 2006). Existing empirical evidence shows the nature of youth unemployment problem is different in developed than developing countries. In developed countries, the difficulties in getting a job as a youth are due to lack of minimum professional skills required in a sophisticated environment with competitive skilled labour supply; in developing countries context, youth unemployment is generally found to rise with educational levels. In the absence of unemployment insurance, only those with family (economic, social and demographic) resources can afford to wait in order to find a good match between their level of qualification and occupations in the labour market. Consequently, most qualified young people cannot afford to be unemployed and end up in the informal sector where productivity and revenues are low. The study as a result further seeks to investigate variations by age group (young and old) in employment sector choice in both Ghana and Tanzania.

The study uses the Urban Household Worker Surveys for Tanzania and Ghana collected in three rounds in pooled models for the respective countries. The two data sets are comparable in the sense that the sampling frames are the respective national household surveys in both countries. The data section provides details on the data.

The paper is structured as follows: A discussion of relevant literature is carried out in section 2. In section 3, the methodology and the conceptual framework of the study are presented. Section 4 outlines the data and in section 5 , the model is specified. Sections 6 and 7 present the empirical results and conclusion respectively.

\section{Literature Review}

Labour markets in most developing countries are segmented into broadly defined formal and informal sectors (Bourguignon et al., 2003). Dualism in labour markets arise when earnings differ for workers with similar characteristics depending on the sector of the economy in which they find work; in essence for dualism to exist, different wages must be paid in different sectors to comparable workers. This is grounded in human capital theory developed by Schultz $(1961,1962)$, Becker $(1962,1964)$ and Mincer $(1962,1974)$. Labour market dualism dates back to Lewis (1954) who expressed the view that the rural sector constitutes a stock of potential workers for the urban formal sector where jobs pay higher wages. This view was subsequently formalized in the Harris and Todaro (1970) model where urban wages are assumed higher than rural wages. Rural workers who choose to search for urban jobs run the risk of becoming unemployed. In equilibrium, expected wages are equated across sectors due to the mass of workers who choose to search in unemployment. Fields (1975) expanded the Harris-Todaro model by assuming urban workers can choose to become informally employed rather than search for higher paying formal 
jobs.

According to Fields (1975), formal sector employment is rationed: those who cannot obtain a formal sector job and cannot afford to search from unemployment work in the informal sector. Informal sector jobs are secondary and workers would be better off with a primary job in the formal sector. The informal sector is seen generally as an inferior alternative to formal sector employment in terms of earnings and other contractual arrangements, but individuals prefer to remain in the informal with the hope to enter the formal sector. The informal sector therefore is seen as providing the poorest and most marginalised people who do not have access to the formal sector with opportunities to earn income (and gain some work experience). Informal sector employment is therefore worse than formal sector employment but superior to unemployment.

The free-entry employment opportunities in the informal sector explains the reason why open unemployment rates in developing countries are comparable to those of developed countries and often considerably lower (Turnham, 1971, 1993; World Bank, 1995; ILO, 2003). According to the proponents of this view, efforts should be made to expand employment in the formal sector for the informal sector to eventually disappear (Moser 1984). Conceptually, this allows a distinction between the informal sector (developing countries) and the shadow economy (developed countries), where the latter is an alternative that is typically illegal rather than a stage.

The other strand of the literature classifies the informal and formal sectors as symmetric and competitive with the two sectors characterised by different production functions. Based on this heterogeneity, some workers are more productive in the formal sector and others in the informal sector, this leads to a preference for informal sector employment compared to formal sector employment. Recent empirical evidence confirm this by pointing to a preference contrary to formal sector employment, many informal sector workers favour their current status to formal sector employment (Thomas, 1992).

Pradhan and van Soest (1995) tested the segmentation theory (staging hypothesis) and the symmetric sector assumption in urban Bolivia to explain the choice between formal sector, informal sector, and not working. The study modelled the choice of employment state in two different choice models, the multinomial logit and the ordered probit model based on the symmetric sector assumption and the staging hypothesis respectively. Subsequently, after estimating the models for both men and women, they find that an ordered model performs better for men while an unordered model fits the data better for women. Pradhan and van Soest (1997) used the same data in a structural labour supply model and find that wage differentials between the formal and informal sector tend to be negative rather than positive, suggesting that non-monetary job characteristics such as job stability, social security and healthcare access among others are needed to explain why many people prefer formal sector jobs. (Note 1)

Within the formal sector, numerous studies point to the existence of formal labour market segmentation, but lack consensus on the existence of public wage premiums, particularly in developing countries. Results generally depend on how selection is modelled. Tansel (1999) examined how individuals are selected into employment type in a multinomial logit model and further carried out decomposition on a selectivity corrected wage equation by gender in Turkey. The study found that all levels of educational attainment increase the probability of joining public administration, state owned enterprises (SOEs) and a covered private sector but reduces the probability of participation in other employment categories and subsequently concluded in terms of segmentation of high wage premiums for men in private sector compared to public administration while women in public administration have higher premiums than their counterparts in the private sector. (Note 2)

In Africa, Lindauer and Sobat (1983), Andersson (1993), Van der Gaag and Vijverberg (1988) have discussed issues relating to labour market segmentation and mostly sought answers to why the preference for formal public sector jobs (Note 3).

Lindauer and Sobat (1983) used data for 1971 household survey of the Tanzanian urban wage labour force to determine the pattern of wage differentials across employment sectors. After standardising by worker characteristics, they found a substantial wage premium for public employees (14\%) over their private sector counterparts. Van der Gaag and Vijverberg (1988) in a similar study on Côte d'Ivoire, used a switching regression model in sector choice analysis and argued that taking account of sector allocation could reverse the direction of the wage differentials that exist between the public and private wage offers. They further emphasize that in addition to possible wage differentials, there are numerous other factors that make a public sector job preferred to a private job. Andersson (1993) identified differences between public and private wage structures and noted that a distinction between formal and informal sectors is important for men, but not for women in Zambia. Skyt-Neilsen and Rosholm (2001) detected a positive average ceteris paribus pay gap in favour of public sector workers in Zambia. In part of a study by Teal (2001), earnings determination in the public and private sectors in Ghana was considered with selectivity correction 
for non-random assignment into the wage sector. The study modelled selection into wage employment in a binary probit model of wage employment for men and women with controls for parental background and education. Findings that emerged from the probit model point to the important role education plays in job attainment by increasing the probability of wage employment for both men and women with higher effect for men. Such empirical evidence generally indicates an inclination towards segmented labour markets due apparently to existing wage gaps. Boudarbat (2004) confirm this fact by the observation of a preference for public sector employment in Africa and a willingness to engage in 'wait' unemployment to secure well paid and stable public sector jobs among the educated.

A study by Glick and Sahn (1997) in a multi sector labour market setting, modelled employment outcomes for men and women in a multinomial logit model of self-employment, private sector wage employment, public sector and non-participation in Guinea. Individual and household characteristics used included levels of education, age, children, education of parents and location of residence. The results indicate for both men and women, more education reduces the likelihood of being self-employed while it strongly increases the likelihood of being in the public sector. In terms of private sector wage employment, more education was found to increase the probability that a woman will be a private wage employee while in the case of men, education reduced the probability of private wage employment although the effect was found to be smaller in absolute value than for self-employment. A similar study by Mariara (2003) adopted the random utility model in a three way multinomial logit model of selection in a multi sector labour market model of public, private and self-employment as the base for normalisation in Kenya. Findings from the study showed education and demographic factors are important determinants for the choice of employment sector and earnings in Kenya. Specifically, some levels of education were found to increase the likelihood of working in the public and private sector compared to self-employment for both men and women. The study further confirmed the importance of education in determining public sector employment in Kenya than private sector employment relative to self-employment. (Note 4)

Rankin, Sandefur and Teal (2010) used the 2004 and 2005 rounds of the Ghana (Note 5) and Tanzania Household Worker surveys in pooled estimations in the investigation the role formal education and time spent in the labour market have in explaining labour market outcomes of urban workers. In a multi sector modelling setting, the labour market was divided into self-employed, employment in small private firms, employment in large private firms, public sector employment and not working. A random utility model was adopted based on the symmetric labour market assumption with covariates such as education, age, marital status, household headship, presence of children and parental education; results from the models indicated education increases the probability of employment in large firms and the public sector in Ghana but no such evidence was found for Tanzania.

Günther and Launov (2012) in a paper on informal employment in developing countries opportunity or last resort, applies an econometric model which allows heterogeneity within the informal sector (upper and lower tier) using 1990 household survey data in the urban labour market in Côte d'Ivoire. The study accounts for sample selection correction into the segments of the informal sector using Heckman (1979) model in different earnings equations specified for segments in the informal sector. Afterwards, it concludes the hypothesis of a dual structure of the informal sector with both voluntary and involuntary employment best describes the empirical data of the Ivorian urban labour market.

In general, the literature on multi sector modelling in employment determination either as an independent study or as part of a modelling framework to correct non-random assignment in earnings models point to a lack of consensus on a segmentation or competition in labour markets in Africa. This makes it imperative to analyse current available data to highlight the determinants of occupational choice especially within two African countries to contribute to the empirical literature.

\section{Methodology}

The main objective of the paper is to investigate determinants of employment sector choice in both Ghana and Tanzania. To this effect, we use the multinomial logit to model of selection into the formal (public and private) and informal sectors in addition to not-working (unemployment) in both countries. The choice between employment and not-working (unemployment) is therefore modelled in a multi sector setting of formal public sector employment, formal private sector employment, informal (self-employment) sector and not-working.

The multinomial logit model extends the binary logit model to more than two choices. This model assumes each individual may select among four mutually exclusive alternatives in the labour market: working in the public sector (indexed $p_{u}$ ), working in the private sector (indexed $p_{r}$ ), self-employment (informal sector) (indexed $s$ ) and not-working (indexed $u$ ). An individual compares the maximum utility attainable given each participation alternative and selects the alternative which yields the maximum utility (Note 6). Preferences are described by a well-behaved 
utility function whose arguments include the household time of the individual, a Hicksian composite commodity and a vector of exogenous constraints on current decision making. (Note 7) Preferences are maximised subject to time and income constraints with no uncertainty.

Let $V_{j i}$ be the maximum utility attainable for individual $i$ if he/she chooses participation status $j=p_{u}, p_{r}, s, u$ and suppose this indirect utility function can be decomposed into a non-stochastic component (S) and a stochastic component $(\epsilon)$ :

$$
V_{j i}=S_{j i}+\epsilon_{j i}
$$

where $S_{j i}$ is a function of observed variables and $\epsilon_{j i}$ is a function of unobserved variables. The probability that individual $i$ will select the $j^{\text {th }}$ participation status is given by

$$
P_{j i}=\operatorname{Pr}\left[V_{j i}>V_{k i}\right] \text { for } k \neq j, k=p_{u}, p_{r}, s, u
$$

or, substituting in from (1),

$$
P_{j i}=\operatorname{Pr}\left[S_{j i}-S_{k i}>\epsilon_{k i}-\epsilon_{j i}\right] \text { for } k \neq j, k=p_{u}, p_{r}, s, u
$$

If the stochastic components have independent and identical Weibull distributions, the difference between the errors $\left(\epsilon_{\mathrm{k} i}-\epsilon_{j i}\right)$ has a logistic distribution and the choice model is multinomial logit (McFadden, 1974). (Note 8)

This is a direct extension of a binary logit model to a dependent variable with several unordered categories since the decision to work in a particular sector is assumed not to be sequential or ordered; rather this depends on the sector in which an individual finds a job. (Note 9)

In order to estimate this model, a functional form of the non-stochastic component of the indirect utility function $S_{j i}$ must be specified. When approximated in a linear form $\left(S_{j i}=\beta j X i\right)$, this yields an empirical specification of the form

$$
P_{j i}=\frac{\exp \left(\beta_{j} X_{i}\right)}{\exp \left(\beta^{\prime}{ }_{p u} X_{i}\right)+\exp \left(\beta^{\prime}{ }_{p r} X_{i}\right)+\exp \left(\beta^{\prime}{ }_{s} X_{i}\right)+\exp \left(\beta^{\prime}{ }_{u} X_{i}\right)}
$$

where $X i$ is a vector of independent variables that explain labour force participation and $\beta_{j}$ is the parameter vector.

In the logit model, it is important to test whether the four sector model simply collapses to the dichotomous model. The dichotomous model is of the form

$$
P_{w i}=\frac{\exp \left(\beta_{w} X_{i}\right)}{\exp \left(\beta^{\prime}{ }_{w} X_{i}\right)+\exp \left(\beta^{\prime}{ }_{n} X_{i}\right)}
$$

where subscripts $w$ and $n$ are for working and not-working (unemployed). This simpler model effectively restricts the parameter for self-employment $(\beta \mathrm{s})$ to equal those of the public sector $(\beta p u)$ and the private sector $(\beta p r)$. The dichotomous model then misspecifies the underlying choice framework unless these coefficients are equal. This can be seen most clearly in terms of the log-odds ratio (Hill 1983). In the logit model, the log-odds ratio of two probabilities is a linear-in-parameters function of the explanatory variables. The log-odds ratio of working and not working derived from the four choice model is:

$$
\ln \left(\frac{P_{p u}+P_{p r}+P_{s}}{P_{n}}\right)=\ln \left[\exp \left(\beta^{\prime}{ }_{p u} X_{i}\right)+\exp \left(\beta^{\prime}{ }_{p r} X_{i}\right)+\exp \left(\beta^{\prime}{ }_{s} X_{i}\right)\right]-\beta^{\prime}{ }_{n} X_{i}
$$

Then if $\beta_{p u}=\beta_{p r}=\beta_{s}$, a simple dichotomous appropriately specifies the choice model.

$$
\ln \left(\frac{p_{w}}{p_{n}}\right)=\ln 2+\beta^{\prime}{ }_{w} X_{i}-\beta^{\prime}{ }_{n} X_{i}
$$

where $P_{p u}+P_{p r}+P_{s}=P_{w}$. If these vectors are not equal, the right hand side of (4.3.10) is nonlinear and will be misspecified with a dichotomous dependent variable and the linear relationship implied by (4.3.6). The dichotomous model assumes that individuals are indifferent between working in the public, private and the informal sector $\left(V_{p u}=V_{p r}=V_{s}\right)$ and that given working, individuals are equally likely to be public, private and informal sector workers $\left(P_{p u}=P_{p r}=P_{s}\right)$.

McFadden (1974) suggests several measures of goodness-of-fit for the multinomial logit model, the likelihood ratio statistic is the most commonly used. Accordingly, the null hypothesis for testing that the four employment type model collapses to the dichotomous model is that $\beta_{p u}=\beta_{p r}=\beta_{s}$, is tested using a likelihood ratio test. The test statistic under the null hypothesis is:

$$
\lambda-2\left[L\left(\beta_{r}\right)-L\left(\beta_{u}\right)\right]
$$


distributed asymptotically as a chi-square variate with $k$ degrees of freedom, where $k$ is the number of restrictions. $L\left(\beta_{r}\right)$ is the log-likelihood function of the four employment status model evaluated under the restriction and $L\left(\beta_{u}\right)$ is the unrestricted log-likelihood function of the model.

Coefficients obtained in the logistic estimation serve to provide a sense of the direction of the effects of the covariates on participation and sector choice in the labour market and cannot be used to indicate the magnitude of impact. To examine the magnitude of impact we calculate the marginal impact of the covariates on the probability of participation and sector choice.

The multinomial logit which allows for more than two categories assumes the errors are independent for each category (employment sector), as a result suffers from the "independence of irrelevant alternatives" (IIA) assumption (Greene, 2003). Under the IIA, no systematic change in coefficients is expected with the exclusion of one of the outcomes from the model. Violation of the IIA assumption implies multinomial logit model is not an efficient and consistent estimator. Consequently, to ascertain the validity of the multinomial logit model, a test for IIA is conducted.

\section{Data}

The study uses the Urban Household Worker Surveys for Tanzania and Ghana collected in three rounds (Note 10) from 2004 to 2006 in pooled sample estimations with year dummies. There exist a small panel and recall dimension of the data but are not used in this study due to the short interval between the survey periods with very low labour market mobility and the large attrition that cannot be explained.

The surveys collect information on incomes, education, labour market experience, household and individual characteristics. For Ghana, the survey covered the four largest urban areas in the country, which are Accra and neighbouring Tema, Kumasi, Takoradi and Cape Coast. In Tanzania, the sample includes six of the largest urban areas, which are Dar es Salaam, Arusha, Iringa, Morogoro, Mwanza and Tanga. The samples are based on a stratified random sample of urban households from the 2000 census in Ghana and the 2000 Household Budget survey in Tanzania with the individual as the unit of analysis.

Figure 1 shows the distribution of log of earnings in the three sectors of employment in Tanzania. As expected, there are large sector differences in earnings with the public sector dominating the private sector and self-employment. The self-employed have the lowest earnings with wide variation (standard deviation), reflecting the likelihood that those running a business with employees or self-employed professionals earn more than the standard informal worker.

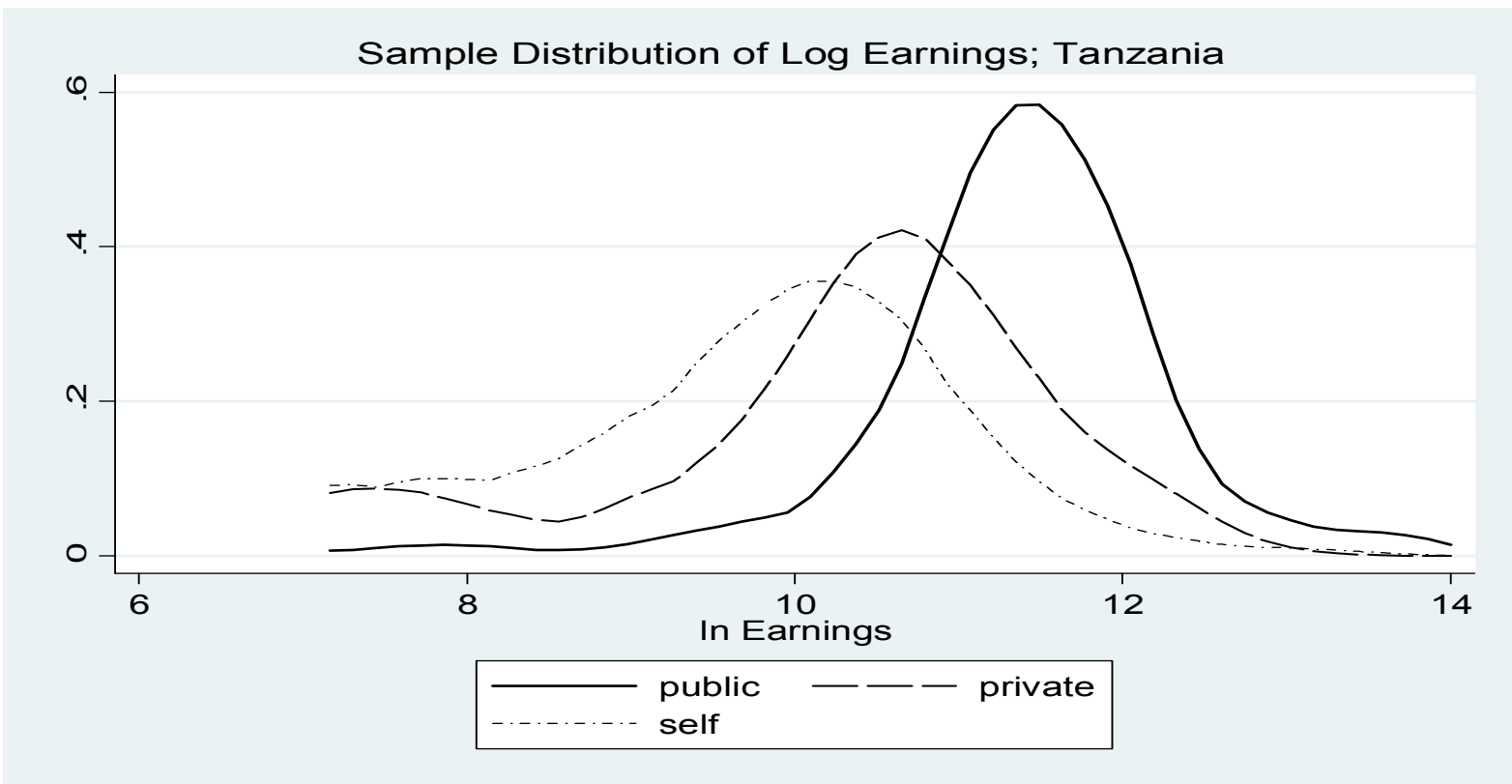

Figure 1 
Distribution of log earnings in Ghana for the three main employment sectors is presented in figure 2. The public sector is the leading sector in terms of earnings followed by private and self-employed. However, comparing Ghana and Tanzania shows sector earnings differentials are not as large in Ghana.

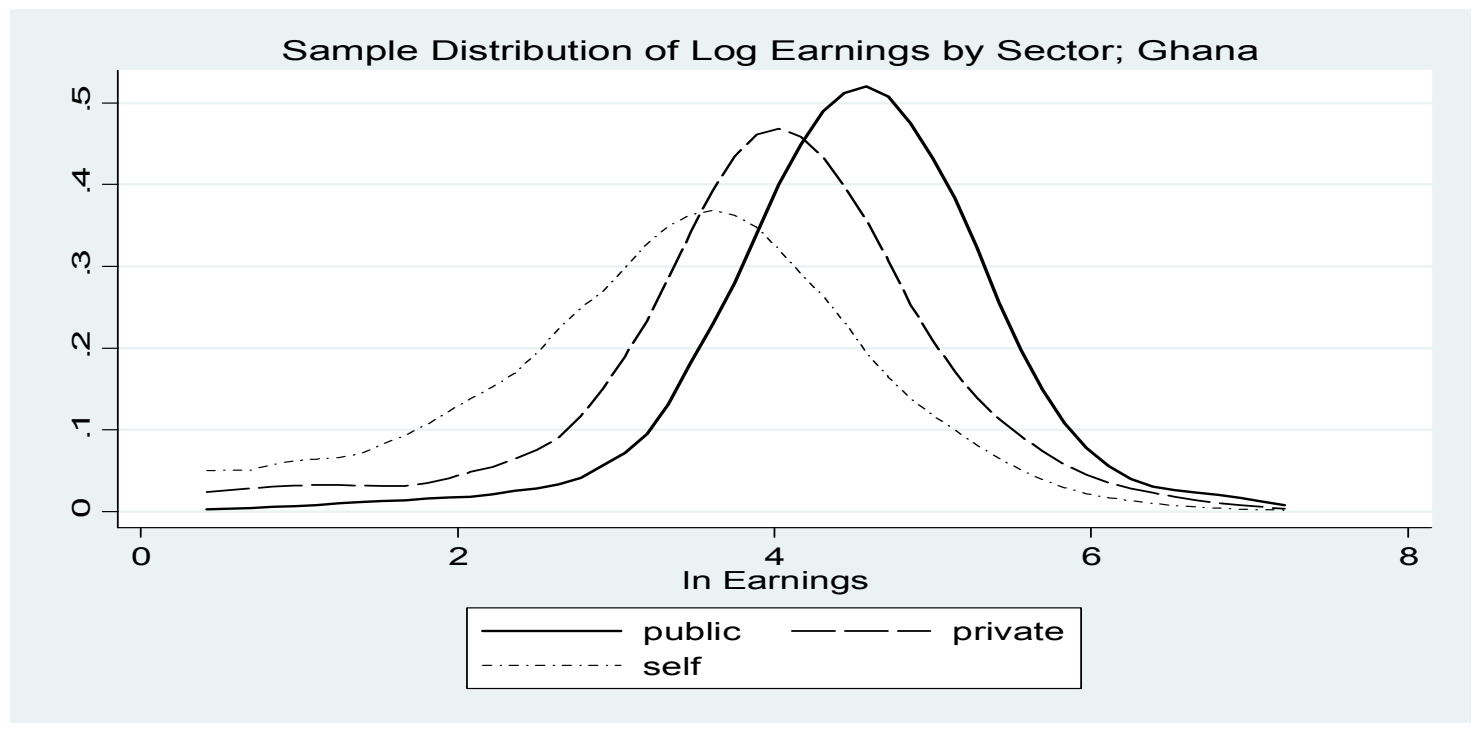

Figure 2

Tables 1 and 2 illustrate the composition of the urban labour force of Tanzania and Ghana for the three years pooled together for each country. Table 1 shows the distribution of the sample by labour force status according to age, years of education, mean, standard deviation and median monthly earnings (converted from local currency to US dollars for comparison with Ghana) for urban workers in Tanzania. The informal sector is the largest sector, employing $42 \%$ of the sample. This is followed by the not-working category (33.3\%) of which unemployment is $16 \%$, and the formal sector (24\%), with private formal sector constituting $17 \%$ of the labour force and the public sector (7.5\%). Average earnings are notably highest in the public sector, followed by private formal employment and then self-employed.

Table 1. Employment status by age, education and monthly earnings for Tanzania

\begin{tabular}{lccccccc}
\hline Employment Status & N & \% Share & Age(yrs) & Education(yrs) & Mean(\$) & Std. Dev. & Median \\
Public & 105 & 7.5 & 43 & 12.1 & 135.58 & $(138.93)$ & 107.84 \\
Private & 236 & 16.8 & 34 & 8.4 & 58.16 & $(61.24)$ & 42.03 \\
Self employed & 594 & 42.4 & 36 & 7.5 & 36.69 & $(65.91)$ & 22.95 \\
Not-working & 467 & 33.3 & 27 & 6.6 & - & - & - \\
Total & $\mathbf{1 4 0 2}$ & $\mathbf{1 0 0}$ & $\mathbf{3 4}$ & $\mathbf{7 . 6}$ & $\mathbf{5 3 . 2 5}$ & $\mathbf{( 8 2 . 4 5 )}$ & $\mathbf{3 1 . 0 0}$ \\
\hline
\end{tabular}

Source: Calculations from UHWS 2004, 2005 and 2006 earnings are converted into U.S. dollars by respective official average yearly exchange rate.

Average years of schooling are higher for workers compared to those not-working (average years of education of the searching unemployed is 6.3 years) and highest for public sector workers (who are also older). The average private sector worker is more educated and earns more than the self-employed although relatively younger. The young and least educated are most likely to be in the not-working (unemployed) category in urban Tanzania as in other places in Africa.

Table 2 provides similar information on employment status by age, years of education and monthly earnings (dollars) for Ghana. The distribution is quite different from that for Tanzania: the private sector is the largest in terms of employment, followed by the not-working category (with unemployment constituting about 20\%), self-employed 
and the public sector. The public sector workers, as in Tanzania, are older and more educated with higher earnings than the private sector worker and the self-employed. However, in Ghana, although the average not-working individual is younger, they are not the least educated.

This suggests that in the Ghanaian labour market people are willing (or able) to wait in unemployment to get employment in the formal sector rather than move into the informal sector (self-employed). Particularly as the average years of education of the searching unemployed is 8.6 years. This is apparently due to existing earnings gaps, prestige and other non-monetary benefits associated with formal sector employment.

Table 2. Employment status by age, education and monthly earnings for Ghana

\begin{tabular}{lccccccc}
\hline $\begin{array}{l}\text { Employment } \\
\text { Status }\end{array}$ & $\mathbf{N}$ & $\begin{array}{c}\mathbf{\%} \\
\text { Share }\end{array}$ & Age(yrs) & Education(yrs) & Mean(\$) & Std. Dev. & Median \\
Public & 152 & 6.3 & 39 & 10.6 & 111.18 & $(100.18)$ & 84.60 \\
Private & 989 & 41.3 & 34 & 9.1 & 87.63 & $(124.44)$ & 57.03 \\
Self employed & 542 & 22.6 & 36 & 6.6 & 74.19 & $(180.20)$ & 44.14 \\
Not-working & 713 & 29.8 & 26 & 8.2 & - & - & - \\
Total & $\mathbf{2 , 3 9 6}$ & $\mathbf{1 0 0}$ & $\mathbf{3 4}$ & $\mathbf{8 . 2}$ & $\mathbf{8 4 . 6 0}$ & $\mathbf{( 1 4 5 . 1 0 )}$ & $\mathbf{5 5 . 1 7}$ \\
\hline
\end{tabular}

Source: Calculations from UHWS 2004, 2005 and 2006 mean and median earnings converted into U.S. dollars by respective official average yearly exchange rate.

\section{Model Specification and Empirical Results}

With the standard neoclassical microeconomic framework underlying participation and sector choice decisions, we estimate equations (4). Variables used in the models influence employment choice by influencing expected earnings and the reservation earnings. The structure of the family has significant effects on participation, particularly for women in the labour market. Most empirical studies find a negative relationship between number of children in the family and the probability of participation by the wife (Kaufman, 1994). This is within the context of division of labour in the household where the husband is the breadwinner and the woman engaged in (reproductive) childrearing and household work. The effect on participation depends on the level of education of the woman; better educated women in particular are less constrained by the need to care for children because they expect higher earnings and can afford to hire domestic help. This is especially relevant in a developing country context (Ghana and Tanzania) where domestic service is affordable among educated women in full-time employment in the formal sector and some self-employed. This notwithstanding, with the rigidities in wage employment, there is the tendency for women to select themselves into the informal sector or unemployment, especially if they have lower levels of education.

Other household characteristics included are dummy variables for access to non-labour income, parent's highest education to capture the effect of networks in access to jobs, and town (region) of residence to control for location opportunities in accessing jobs.

Parent's education is measured as the highest level of education attained by both mother and father separately. It is expected that more educated parents will have more social capital in terms of networks that facilitate job search and attainment. Personal characteristic variables included are age, sex, level of education and marital status. Age controls for life cycle and any potential labour market experience. A home ownership variable as a proxy for assets was initially included but dropped given low response rate (less than $50 \%$ of sample) and was insignificant when included, instead resource based measure of access to non-labour income is used (from the question do you receive any income apart from labour income). All estimations include year dummies to control for any macroeconomic trend.

\section{Results}

Although the multinomial logit model intuitively seems to be an appropriate methodology for the analysis of occupational choice, the Independence of Irrelevant Alternatives - IIA property (i.e. the odds ratio of choosing existing alternatives are assumed to be independent of the other alternatives) is tested by using McFadden et al (1977) likelihood ratio statistic. The test statistic is calculated as 2[the maximized log likelihood value of unrestricted model - the maximized log likelihood value of restricted model]. It is an asymptotic chi-square distribution with degrees of 
freedom equal to the number of parameters in the restricted model. Across the two countries, the tests indicate that the multinomial logit model does not violate the IIA, hence appropriate for our sector choice models.

Results from multi sector models estimated for the two countries are presented in Table 3 (average partial effects), coefficients are presented in appendix A1. A likelihood ratio test of the null hypothesis of equality of coefficients between any pair of employment sectors $\left(\beta \_p u=\beta \_p r=\beta \_s\right)$ in both models is rejected at $1 \%$ level of significance. This is an indication that the labour market is heterogeneous and the decomposition into public, private, self-employment and not-working is suitable. In addition, a likelihood ratio test is also used to test for multiple exclusion restriction; the null hypothesis tested is that all slope coefficients in each model are simultaneously equal to zero. Across models, we reject the null hypothesis at $1 \%$ level of significance.

In Tanzania, older people are less likely to be found in the not-working category, as age increases the probability of employment in all three sectors. The different education level dummies relative to no education decrease the probability not-working and self-employment in Tanzania and increase employment probabilities in the two formal sectors particularly in the public sector. In Tanzania, being a man increases the likelihood of self-employment and private sector employment by $5 \%$ and $12 \%$ respectively but at the same time reduces the probability of not-working and public sector employment. Father's highest education level decreases the probability of not-working but increases self-employment although at $10 \%$ in Tanzania. Access to non-labour income is associated with an increased probability of not-working and a reduced probability of self-employment in Tanzania. These results are generally consistent when we estimate the model with the narrower searching unemployed category as the reference group (Results available or request).

Table 3. Average partial effects from multi sector choice models

\begin{tabular}{|c|c|c|c|c|c|c|c|c|}
\hline & \multicolumn{4}{|c|}{ Tanzania } & \multicolumn{4}{|c|}{ Ghana } \\
\hline & Not-working & Self & $\begin{array}{l}\text { Private } \\
\text { Sector }\end{array}$ & $\begin{array}{l}\text { Public } \\
\text { Sector }\end{array}$ & Not-working & Self & $\begin{array}{l}\text { Private } \\
\text { Sector }\end{array}$ & $\begin{array}{l}\text { Public } \\
\text { Sector }\end{array}$ \\
\hline Age & $\begin{array}{l}-0.013 * * * \\
(0.001)\end{array}$ & $\begin{array}{l}0.006 * * * \\
(0.001)\end{array}$ & $\begin{array}{l}0.003^{* * *} \\
(0.001)\end{array}$ & $\begin{array}{l}0.003 * * * \\
(0.000)\end{array}$ & $\begin{array}{l}-0.013 * * * \\
(0.001)\end{array}$ & $\begin{array}{l}0.006^{* * *} \\
(0.001)\end{array}$ & $\begin{array}{l}0.005 * * * \\
(0.001)\end{array}$ & $\begin{array}{l}0.002 * * * \\
(0.001)\end{array}$ \\
\hline Primary & $\begin{array}{l}-0.068^{* *} \\
(0.030)\end{array}$ & $\begin{array}{l}-0.001 \\
(0.046)\end{array}$ & $\begin{array}{l}0.003 \\
(0.039)\end{array}$ & $\begin{array}{l}0.053 * * * \\
(0.018)\end{array}$ & $\begin{array}{l}-0.030 \\
(0.023)\end{array}$ & $\begin{array}{l}-0.070 * * * \\
(0.019)\end{array}$ & $\begin{array}{l}0.054 * \\
(0.028)\end{array}$ & $\begin{array}{l}0.047 * * \\
(0.022)\end{array}$ \\
\hline Secondary & $\begin{array}{l}-0.073 * * \\
(0.033)\end{array}$ & $\begin{array}{l}-0.109 * * \\
(0.047)\end{array}$ & $\begin{array}{l}0.019 \\
(0.040)\end{array}$ & $\begin{array}{l}0.112 * * * \\
(0.020)\end{array}$ & $\begin{array}{l}0.057 * * \\
(0.028)\end{array}$ & $\begin{array}{l}-0.188 * * * \\
(0.028)\end{array}$ & $\begin{array}{l}0.048 \\
(0.034)\end{array}$ & $\begin{array}{l}0.083 * * * \\
(0.023)\end{array}$ \\
\hline Tertiary & $\begin{array}{l}-0.043 \\
(0.109)\end{array}$ & $\begin{array}{l}-0.304 * * * \\
(0.086)\end{array}$ & $\begin{array}{l}0.132 * * \\
(0.068)\end{array}$ & $\begin{array}{l}0.207 * * * \\
(0.032)\end{array}$ & $\begin{array}{l}0.014 \\
(0.035)\end{array}$ & $\begin{array}{l}-0.189 * * * \\
(0.037)\end{array}$ & $\begin{array}{l}0.074 * \\
(0.041)\end{array}$ & $\begin{array}{l}0.101 * * * \\
(0.024)\end{array}$ \\
\hline Sex & $\begin{array}{l}-0.143 * * * \\
(0.017)\end{array}$ & $\begin{array}{l}-0.051 * * \\
(0.023)\end{array}$ & $\begin{array}{l}0.124 * * * \\
(0.020)\end{array}$ & $\begin{array}{l}0.031 * * * \\
(0.011)\end{array}$ & $\begin{array}{l}-0.038 * * \\
(0.016)\end{array}$ & $\begin{array}{l}-0.171 * * * \\
(0.015)\end{array}$ & $\begin{array}{l}0.184 * * * \\
(0.017)\end{array}$ & $\begin{array}{l}0.025 * * \\
(0.011)\end{array}$ \\
\hline Marriage & $\begin{array}{l}-0.040 \\
(0.040)\end{array}$ & $\begin{array}{l}0.021 \\
(0.036)\end{array}$ & $\begin{array}{l}0.003 \\
(0.037)\end{array}$ & $\begin{array}{l}0.003 \\
(0.016)\end{array}$ & $\begin{array}{l}-0.092 * * * \\
(0.023)\end{array}$ & $\begin{array}{l}0.064 * * * \\
(0.020)\end{array}$ & $\begin{array}{l}0.025 \\
(0.027)\end{array}$ & $\begin{array}{l}0.003 \\
(0.015)\end{array}$ \\
\hline Children & $\begin{array}{l}-0.006 \\
(0.038)\end{array}$ & $\begin{array}{l}0.062 \\
(0.043)\end{array}$ & $\begin{array}{l}-0.022 \\
(0.041)\end{array}$ & $\begin{array}{l}-0.007 \\
(0.019)\end{array}$ & $\begin{array}{l}0.069 * * * \\
(0.026)\end{array}$ & $\begin{array}{l}0.008 \\
(0.024)\end{array}$ & $\begin{array}{l}-0.088 * * * \\
(0.030)\end{array}$ & $\begin{array}{l}0.011 \\
(0.018)\end{array}$ \\
\hline $\begin{array}{l}\text { Non-Labour } \\
\text { income }\end{array}$ & $\begin{array}{l}-0.167 * * * \\
(0.061)\end{array}$ & $\begin{array}{l}-0.114 * * * \\
(0.043)\end{array}$ & $\begin{array}{l}-0.026 \\
(0.040)\end{array}$ & $\begin{array}{l}0.013 \\
(0.016)\end{array}$ & $\begin{array}{l}0.010 \\
(0.021)\end{array}$ & $\begin{array}{l}0.038 * * \\
(0.019)\end{array}$ & $\begin{array}{l}-0.039 * \\
(0.022)\end{array}$ & $\begin{array}{l}-0.009 \\
(0.011)\end{array}$ \\
\hline $\begin{array}{l}\text { Father's } \\
\text { education }\end{array}$ & $\begin{array}{l}-0.010 \\
(0.003)\end{array}$ & $\begin{array}{l}0.006 * \\
(0.003)\end{array}$ & $\begin{array}{l}0.002 \\
(0.003)\end{array}$ & $\begin{array}{l}0.000 \\
(0.002)\end{array}$ & $\begin{array}{l}-0.007 * * \\
(0.003)\end{array}$ & $\begin{array}{l}-0.005 \\
(0.003)\end{array}$ & $\begin{array}{l}0.008 * * \\
(0.004)\end{array}$ & $\begin{array}{l}0.004^{*} \\
(0.002)\end{array}$ \\
\hline $\begin{array}{l}\text { Mother's } \\
\text { education }\end{array}$ & $\begin{array}{l}0.0001 \\
(0.003)\end{array}$ & $\begin{array}{l}-0.001 \\
(0.004)\end{array}$ & $\begin{array}{l}0.002 \\
(0.003)\end{array}$ & $\begin{array}{l}0.001 \\
(0.002)\end{array}$ & $\begin{array}{l}0.002 \\
(0.003)\end{array}$ & $\begin{array}{l}-0.005 \\
(0.004)\end{array}$ & $\begin{array}{l}0.009 * * \\
(0.004)\end{array}$ & $\begin{array}{l}-0.002 \\
(0.002)\end{array}$ \\
\hline $\begin{array}{l}\text { Dar es } \\
\text { /Accra }\end{array}$ & $\begin{array}{l}-0.043 \\
(0.029)\end{array}$ & $\begin{array}{l}0.047 * \\
(0.027)\end{array}$ & $\begin{array}{l}0.026 \\
(0.027)\end{array}$ & $\begin{array}{l}-0.004 \\
(0.012)\end{array}$ & $\begin{array}{l}-0.358 * * * \\
(0.023)\end{array}$ & $\begin{array}{l}0.052 * * * \\
(0.017)\end{array}$ & $\begin{array}{l}0.279 * * * \\
(0.019)\end{array}$ & $\begin{array}{l}0.027 * * * \\
(0.010)\end{array}$ \\
\hline $\begin{array}{l}\text { Test of IIA } \\
\chi^{2}(24) \\
N\end{array}$ & 1.75 & 78.59 & 26.73 & 7.77 & 17.75 & 67.39 & $\begin{array}{r}32.99 \\
2,297\end{array}$ & 64.01 \\
\hline
\end{tabular}


Results for Ghana reinforce findings in the baseline model that informal (self-employed) sector is the least preferred sector of employment by the educated and significantly so by the highly educated as all levels of education reduce the probability of self-employment. Notably, education is a vital determinant of employment in the public sector in Ghana similar to Tanzania as all levels of education are found to monotonically increase the probability of employment in the sector. Men are more likely than women to be in formal private and public sectors in the Ghanaian labour market. Although this is subject to further research, it may connote some form of discrimination in the labour market whereby formal sector employers may have a preference for men conditioning on education and all other demographic and household characteristic. Also, with little flexibility and fixed hours of work in wage employment particularly in the private sector in the African context, women may select themselves into the informal sector in order to cope with the need to care for children and domestic work to the extent that this sector enables them to combine productive work and care work. Similarly, being married is associated with increased probability of self-employment and decreased probability of not-working in addition to a 7\% increased probability of not-working and a $9 \%$ decreased probability of private sector employment by individuals with children. This highlights the need to provide care at home and the demands of formal sector employment particularly in the private sector that deters individuals with children. Residence in Accra is associated with increased probability of employment in all sectors and given that Accra is the capital city, this is an indication of differences in employment opportunities that exist in the country. In contrast to Tanzania, parent's highest education level particularly father's education is found to increase the probability of formal sector employment mainly in the private sector.

Analysis of variation in sector choice according to age group is carried out to investigate heterogeneity in job attainment by age. Due to the very small samples in some of the categories when we split the data by age group, we are unable to estimate the models separately for young (age 15-35) and older (age 36-64) people for each country. Instead, a dummy variable to capture age group effect is introduced into the initial models for the respective countries.

Average partial effects of results with young dummy for both Tanzania and Ghana are presented in Table 4. In both countries, being young is associated with increased probability of not-working. Given that the samples do not include students, since it can be argued this group will most likely consist of individuals in school who are not working or looking for jobs, the results shed light on the challenges young people face in obtaining jobs in both countries due possibly to lack of experience. In Tanzania, young people have reduced probability of employment in the public sector $(10 \%)$, however in Ghana, the probability of employment in all three employment sectors are reduced (negative) among young compared to the old. While marginal effects of self-employment and private sector employment for young are insignificant in the case of Tanzania, the results suggests young people in the Ghanaian labour market may have more difficulties in terms of job attainment than their counterparts in Tanzania.

Further analysis of the effect of age is carried out by examining the probability of selection into the four labour market statuses. 
Table 4. Average partial effects from multinomial logit model with young dummy

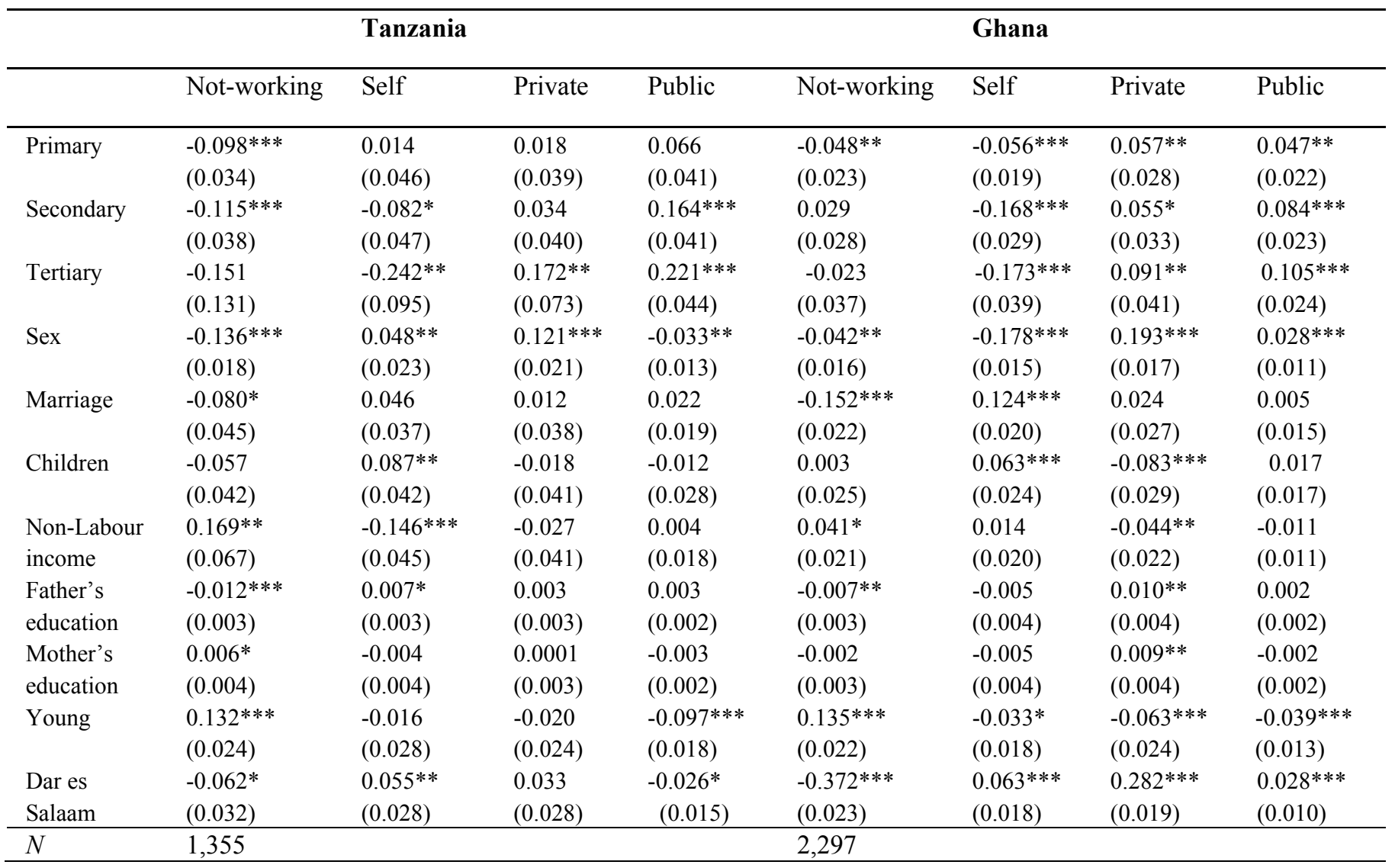

Note: reference category for young (15-35years) age group is Old (36-64 years)

Conditioning on all the covariates (education and family background), these probabilities are presented in appendix table A2. In Tanzania, the probability of not-working decreases with age until age sixty when the probability of not-working increases, this is expected since at sixty years, individuals are supposed to retire, particularly in the formal sector. On the other hand, the probability of self-employment is found to increase with age with a marginal decrease at sixty years. In the two formal sectors, the results confirm earlier findings of the important role of age in job attainment as the probabilities increase with age and begin to decrease as individuals get older towards the retirement age of 60 years.

Similarly for Ghana as shown in Table A3, the probability of not-working decreases with age until age sixty when the probability increases. Also age is found to be important in determining employment in the informal sector (self-employment) in Ghana as the probabilities increase with age, although not monotonic; this connotes the possibility of access to funds to set up business which older people would have more channels than younger people. This could also be due to the fact that when people get older in the labour market, they require some level of flexibility on the job which may be available in the informal sector. Similarly, within the two formal sectors, the results suggests the importance of age in determining employment in these sectors cannot be over emphasised as the probability of employment within these sectors generally increase with age.

\section{Conclusion and Policy Implications}

The study investigates the determinants of employment sector choice in the urban labour markets of both Ghana and Tanzania. To this end, the multinomial logit model of employment determination into specific sectors was used to ascertain insight into individual sector choice. Consistency checks on the result were further conducted by a re-specification of the models with searching unemployed in the labour markets as the reference category instead of the broader not-working category (result available on demand).

Results suggest that both labour markets are characteristic of a preference for formal sector employment with education as all levels of education are found to increase the probability of public and private sector (formal sector) 
employment and decrease the probability of self-employment (informal sector) and not-working in both labour markets although in Ghana, education (years and secondary level) increases the probability of not-working. These advantages with education are also reflected along gender lines in both labour markets with men having high probability of selection into formal sector employment with the reverse for self-employment and not-working (unemployment). Results based on age differences in labour market attainment point to the existence challenges young people face in accessing jobs in both Ghana and Tanzania as we find high probabilities of not-working to be associated with young relative to older people. A further investigation of the age and education indicates the educated elderly in the two labour markets are less likely to be found not working, an emphasis on the fact that educated young people are more prone to unemployment in the two labour markets.

Overall, our results suggest a preference for formal (public and private in order) sector employment in sector selection in both labour markets but a stricter preference in the Ghanaian labour market relative to Tanzania. Although we do not incorporate earnings, the strong education effects found is a reflection of the wage effect in sector choice in both countries. Previous studies in different parts of Africa confirm the fact that education is important in determining which sector of the labour market an individual works. Consistent for most part of our results, Glick et al. (1997) found that for men and women in Guinea, more education reduces the likelihood of being in self-employment while it strongly increases the likelihood of being in the public sector. Similarly, Vijverberg (1993) found that for men and women in Cote d'Ivoire, the probability of being in wage employment rises with education level while the probability of non-agricultural self-employment falls with additional schooling. On Ghana, Glewwe (1991) confirms our finding of a strict preference for formal sector jobs and hierarchical nature of the preference by the finding that schooling is positively associated with entry into wage employment and among wage employees, those with better education are more likely to be in the public sector than in the private sector.

One implication is that public policy should be targeted towards making the informal sector attractive to the highly educated particularly in Ghana. Assistance in the form of training and financial support could make activities and prospects in the sector more secured (less risky). Efforts should also be made to formalise activities of the informal sector through registration of businesses and advocacy for keeping formal accounts to make the sector an attractive partner in development to the financial sector. In this way, enterprises in the informal sector can readily access financial support in the form of loans and venture capital. The process of formalisation of the informal sector will eventually expand the private sector.

\section{References}

Andersson, P. (1993). Labour market structure in a controlled economy: The case of Zambia. Ekonomiska Studier, No. 37, Department of Economics, University of Gothenburg.

Appleton, S., Collier, P., \& Horsnell, P. (1990). Gender, education and employment in Cote D'viore. Social Dimensions working paper no. 8, The World Bank.

Becker, G. S. (1962). Investment in human capital. Journal of Political Economy, LXX Suplement, 9-49.

Boudarbat, B. (2004). Employment sector choice in a developing labour market. Mimeo, Department of Economics, University of British Columbia.

Bourguignon, F., Robilliard, A., \& Robinson, S. (2003). Representative versus real households in the macro-economic modelling of inequality. DIAL Working Paper no. DT/2003/10. Development, Institutions and Analysis de Long Term, Paris.

Fields, G. S. (1975). Rural urban migration, urban unemployment and underemployment, and job-search activity in LDCs. Journal of Development Economics, 2(2), 165-187.

Fields, G. S. (2005). A guide to multi sector labour market models. Social Protection Discussion paper series, no. 0505, The World Bank.

Greene, W. H., \& Hensher, D. A. (2010). Modelling ordered choices. Cambridge University Press, Cambridge.

Günther, I., \& Launov, A. (2012). Informal employment in developing countries: opportunity or last resort?. Journal of development economics, 97(1), 88-98.

Hart, K. (1985). The informal economy. Cambridge Anthropology, 10(2), 54-58

Heckman, J., \& Sedlacek, G. (1985). Heterogeneity, aggregation and market wage functions: an empirical model of self-selection in the labour market. Journal of Political Economy, 93, 1077-1125.

International Labour Office. (2003). Global employment trends 2003. Geneva: ILO. 
International Labour Office. (2006). Global employment trends for youth. Geneva: ILO.

Krishnan, P., Sellasie, T., \& Dercon, S. (1998). The urban labour market during structural adjustment: Ethiopia 1990-1997. CSAE WPS/98-99. Centre for the Study of African Economies, Oxford University.

Lewis, W. A. (1954). Economic development with unlimited supplies of labour. The Manchester School, 22, 141-145.

Lindauer, D., \& Sabot, R. (1983). The public-private wage differential in a poor urban economy. Journal of Development Economics, 12(3), 137-152.

Lubell, H. (1990). The informal sector in the 1980s and 1990s. Development centre, O.E.C.D., Paris.

Maloney, W. F. (2004). Informality revisited. World Development, 32(7), 1159-1178.

Perry, G. E., Maloney W. F., Arias, O. S., Fajnzylber, P., Mason, A. D., \& Saavedra-Chanduvi, J. (2007). Informality: exit and exclusion. Washington DC: The World Bank. World Bank Latin America and Caribbean Studies.

Pradhan, M. A., \& van Soest, A. (1995). Formal and informal sector employment in urban areas of Bolivia. Labour Economics, 2, 275-97.

Pradhan, M., \& van Soest, A. (1997). Household labour supply in urban areas of Bolivia. Review of Economics and Statistics, 79, 300-310.

Todaro, M. P. (1969). A model of labour migration and urban unemployment in Less Developed Countries. American Economic Review, 39, 138-148.

Turnham, D. (1971). The employment problem in less developed countries. Paris Development Centre of the Organisation for Economic Co-operation and Development.

Van der Gaag, J., Stelcner, M., \& Vijverberg, W. (1988, May). A switching regression model for wage determinants in the public and private sectors of a developing country. The Review of Economics and Statistics, 70(2), 244-252.

Vijverberg, W. (1993). Educational investment and returns for women and men in Cote d'Ivoire. The Journal of Human Resources, (4), Special issue: Symposium on investments in women's Human Capital and Development, Autumn, 933-974.

World Bank. (1995). World Development Report 1990. Washington: World Bank.

Xiaodong, G., \& van Soest, A. (2002). Wage differentials and mobility in the urban labour market: a panel data analysis for Mexico. Labour Economics, 9, 513-529.

\section{Notes}

Note 1. Strassmann (1987) in a similar manner found out that $71 \%$ of home workers in Lima would require a considerable financial incentive to move to the formal sector.

Note 2. Examples of other studies on segmentation include Magnac (1991) in Columbia and Grinling (1991) in the analysis of urban labour markets in Costa Rica.

Note 3. Thomas and Vallee (1996) examine earnings in the informal, formal, and regulated sectors within the manufacturing sector in Cameroon. Appleton, Collier, and Horsnell (1990) considered the private and public sector distinction in Cote d'Ivoire with non-participation as a base category in addition to a three-sector model of wage sector, with the private sector split into union and non-union segments.

Note 4. Sackey (2005), adopted the random utility model in a study on female labour force participation and fertility in Ghana and found a high rate of participation by women, with education as the key determinant of participation.

Note 5. In part of a study by Glewwe (1991), the adoption of a random utility model of sector choice led the conclusion that schooling is positively associated with entry into wage employment and among wage employees, those with better education are more likely to be in the public than the private sector.

Note 6 . The specification does not allow the possibility of working concurrently in more than one sector. This restriction may be unreasonable if individuals work both in a family business and in the formal sector. However, the data does not have information on multiple job holding. Each person reports one current principal employment status. 
Note 7. The model treats non labour income as exogenous. Although this may be an unrealistic assumption (particularly for the informal sector), it is important due to the need to link theory with the data in the absence of appropriate instruments.

Note 8. Weibull distribution has a unimodal bell shape roughly similar to the normal distribution.

Note 9. Some individuals decide to join the informal sector while awaiting modern wage employment job, others also leave modern sector jobs to become self-employed in the informal sector and vice versa. The choices made do not follow any particular order and this serves as a justification for the MNL model.

Note 10. Surveys were conducted by the Centre for the Study of African Economies, Oxford University.

\section{Appendices}

Table A1. Multinomial logit results for sector choice

\begin{tabular}{|c|c|c|c|c|c|c|}
\hline & & Tanzania & & & Ghana & \\
\hline & Self & Private & Public & Self & Private & Public \\
\hline & & Sector & Sector & & Sector & Sector \\
\hline Age & $0.497 * * *$ & $0.453 * * *$ & $0.855 * * *$ & $0.447 * * *$ & $0.129 * * *$ & $0.200 * * *$ \\
\hline & $(0.053)$ & $(0.053)$ & $(0.111)$ & $(0.056)$ & $(0.047)$ & $(0.075)$ \\
\hline $\mathrm{Age}^{2}$ & $-0.006 * * *$ & $-0.005 * * *$ & $-0.009 * * *$ & $-0.005 * * *$ & $-0.001 *$ & $-0.002 *$ \\
\hline & $(0.001)$ & $(0.001)$ & $(0.001)$ & $(0.001)$ & $(0.001)$ & $(0.001)$ \\
\hline Primary & $0.658^{* *}$ & $0.591^{*}$ & $1.820^{* *}$ & $-0.379^{*}$ & 0.275 & $0.919 * *$ \\
\hline & $(0.326)$ & $(0.355)$ & $(0.811)$ & $(0.211)$ & $(0.209)$ & $(0.423)$ \\
\hline Secondary & 0.446 & $0.770^{* *}$ & $3.511 * * *$ & $-1.735 * * *$ & -0.342 & $0.868^{*}$ \\
\hline & $(0.365)$ & $(0.388)$ & $(0.810)$ & $(0.289)$ & $(0.250)$ & $(0.453)$ \\
\hline Tertiary & -0.478 & 1.150 & $3.973 * * *$ & $-1.647 * * *$ & -0.108 & $1.351 * * *$ \\
\hline & $(1.140)$ & $(1.115)$ & $(1.351)$ & $(0.368)$ & $(0.301)$ & $(0.488)$ \\
\hline sex & $1.256 * * *$ & $1.738 * * *$ & $0.664^{* *}$ & $-1.280 * * *$ & $0.444 * * *$ & 0.384 \\
\hline & $(0.206)$ & $(0.215)$ & $(0.311)$ & $(0.175)$ & $(0.150)$ & $(0.234)$ \\
\hline Married & 0.431 & 0.336 & 0.668 & $1.244 * * *$ & $0.884 * * *$ & $0.832 * * *$ \\
\hline & $(0.401)$ & $(0.453)$ & $(0.521)$ & $(0.222)$ & $(0.215)$ & $(0.314)$ \\
\hline Children & 0.234 & -0.084 & -0.498 & -0.304 & $-0.516^{* *}$ & -0.176 \\
\hline & $(0.391)$ & $(0.447)$ & $(0.643)$ & $(0.259)$ & $(0.241)$ & $(0.369)$ \\
\hline Non-Labour income & $-1.877 * * *$ & $-1.433 * *$ & $-1.540 * *$ & 0.241 & -0.103 & -0.168 \\
\hline & $(0.621)$ & $(0.644)$ & $(0.687)$ & $(0.206)$ & $(0.176)$ & $(0.252)$ \\
\hline Father's education & $0.108 * * *$ & $0.089 * * *$ & $0.135 * * *$ & -0.032 & -0.046 & 0.048 \\
\hline & $(0.033)$ & $(0.034)$ & $(0.044)$ & $(0.037)$ & $(0.031)$ & $(0.048)$ \\
\hline Mother's education & -0.009 & 0.009 & -0.042 & -0.021 & 0.039 & -0.028 \\
\hline & $(0.035)$ & $(0.037)$ & $(0.051)$ & $(0.038)$ & $(0.031)$ & $(0.049)$ \\
\hline Dar es Salaam / Accra & 0.468 & 0.455 & -0.138 & $3.232 * * *$ & $3.874 * * *$ & $3.626 * * *$ \\
\hline & $(0.294)$ & $(0.326)$ & $(0.389)$ & $(0.406)$ & $(0.392)$ & $(0.428)$ \\
\hline Constant & $-12.126 * * *$ & $-11.171 * * *$ & $-24.178 * * *$ & $-6.383 * * *$ & $-2.453 * * *$ & $-8.056 * * *$ \\
\hline & $(1.040)$ & (1.038) & $(2.544)$ & $(0.965)$ & $(0.820)$ & (1.485) \\
\hline$\chi^{2}$ (D.F) & $1153.58(42)$ & & & $1248.48(42)$ & & \\
\hline Log-likelihood & -1085.691 & & & -1850.683 & & \\
\hline Pseudo- $\mathrm{R}^{2}$ & 0.347 & & & 0.252 & & \\
\hline Observations & 1,355 & & & 2,297 & & \\
\hline
\end{tabular}


Table A2. Predicted individual probabilities of occupation type by Age; Tanzania

\begin{tabular}{lllll}
\hline Age in years & Not-working & Self-employment & Private & Public \\
\hline 20 & $0.530 * * *$ & $0.285 * * *$ & $0.174 * * *$ & $0.011^{* *}$ \\
& $(0.029)$ & $(0.035)$ & $(0.033)$ & $(0.011)$ \\
30 & $0.249 * * *$ & $0.465 * * *$ & $0.235^{* * *}$ & $0.051^{* *}$ \\
& $(0.013)$ & $(0.018)$ & $(0.017)$ & $(0.011)$ \\
40 & $0.132 * * *$ & $0.539 * * *$ & $0.224 * * *$ & $0.104 * * *$ \\
50 & $(0.014)$ & $(0.028)$ & $(0.024)$ & $(0.018)$ \\
& $0.130 * * *$ & $0.549 * * *$ & $0.193 * * *$ & $0.128 * * *$ \\
60 & $(0.023)$ & $(0.048)$ & $(0.034)$ & $(0.030)$ \\
& $0.242 * * *$ & $0.504 * * *$ & $0.153 * * *$ & $0.101 * * *$ \\
\hline
\end{tabular}

Source: estimated from multinomial logit model for Tanzania

Table A3. Predicted individual probabilities of occupation type by Age; Ghana

\begin{tabular}{lllll}
\hline & & & & \\
\hline Age in years & Not-working & Self-employment & Private & Public \\
\hline 20 & $0.481^{* * *}$ & $0.101^{* * *}$ & $0.385^{* * *}$ & $0.034^{* * *}$ \\
& $(0.024)$ & $(0.013)$ & $(0.021)$ & $(0.009)$ \\
30 & $0.235^{* * *}$ & $0.282^{* * *}$ & $0.427^{* * *}$ & $0.056^{* * *}$ \\
& $(0.012)$ & $(0.012)$ & $(0.012)$ & $(0.006)$ \\
40 & $0.148^{* * *}$ & $0.347^{* * *}$ & $0.429^{* * *}$ & $0.075^{* * *}$ \\
50 & $(0.014)$ & $(0.018)$ & $(0.018)$ & $(0.010)$ \\
& $0.166^{* * *}$ & $0.259^{* * *}$ & $0.472^{* * *}$ & $0.104^{* * *}$ \\
60 & $(0.018)$ & $(0.020)$ & $(0.022)$ & $(0.015)$ \\
& $0.279^{* * *}$ & $0.093^{* * *}$ & $0.502^{* * *}$ & $0.126^{* * *}$ \\
\hline
\end{tabular}

Source: Estimated from multinomial logit model for Ghana 